\title{
CORRELATIONS BETWEEN THE EVOLUTION OF INTERNATIONAL RELATIONS AND PERFECTING THE INTERNATIONAL MEANS OF PROTECTING HUMAN RIGHTS
}

\author{
E. Paraschiv
}

\section{Elena Paraschiv}

Faculty of Law and Public Administration, Râmnicu Vâlcea, "Spiru Haret" University, Râmnicu Vâlcea, Romania

*Correspondence: Elena Paraschiv, Râmnicu Vâlcea, 30 General Magheru St., Vâlcea, Romania

E-mail: e.paraschiv.dvl@ spiruharet.ro

\section{Abstract}

The evolution of relations between states made necessary the establishment, at an international level, of certain behavioural regulations and fundamental principles, whose violation may cause prejudices to the collaboration relationships developed among states. Thus, over time these were consecrated by customary rules, treaties or other international conventions, imperative norms of conduct, which are strictly imposed to all partners at international juridical relations ${ }^{l}$.

Moreover, international norms which aim at respecting the fundamental human rights and liberties were adopted, thus contributing to the defense of the universal values of humanity.

Key words: international methods of protecting human rights, improvement, international relations, correlation, historical evolution

\section{Introduction}

Over the years, societies defined, implicitly or explicitly, in juridical terms or without using them, the rights and obligations of their members, taking into account their needs and social aspirations, so that the ,history of the human rights is mistaken for the history of humanity"2.

The problem of protecting human rights is fundamentally related to the relations between humans and their social environment, which are not meant to last, thus legally, abstract rights do not exist, as the form of right, like any other normative system, is in itself the reflection of a certain social order ${ }^{3}$.

\section{The evolution of international means of human rights protection}

Even though there were some concepts of a humanistic nature in the Antiquity period or in the political theory of the Middle Ages, the concept of ,human rights" was consolidated in the period of intellectual preparation for the bourgeois revolutions in Europe ${ }^{4}$, and the apparition of a coherent theory and some actual practices regarding the protection of these

\footnotetext{
${ }^{1}$ Duculescu V., 2002, Instituții de drept public şi relații internaționale în dinamică, Lumina Lex Publishing, Bucharest, p. 73.

${ }^{2}$ Mbaye K., 1991, Les droits de l'homme et des peuples, in Droit International, Bilan et Perspectives, coordinator Mohammed Bedjaoui, Pedone Publishing, Paris, p. 111.

${ }^{3}$ Tomuschat Ch., 1981, International Standards and Cultural Diversity, HR Teaching Publishing, p. 2.

${ }^{4}$ Năstase A., 2004, Destinul contemporan al dreptului internaţional. Reflecții dintr-o perspectivă europeană, Universitatea „Nicolae Titulescu” Publishing, Bucharest, p. 173.
} 
rights is the product of an extended period, in which time the premises necessary for the crystallisation of juridical basis of human rights have been accumulating ${ }^{5}$.

Some of the norms of international humanitarian law are of a customary nature, although many of them have found their expression in international conventions, as a result of the growing preoccupation for protection, on an universal level, a series of juridical and moral values of humanity.

The first conventional norms targeted the humanization of war, combating the slave trade and, generally, with human beings, as well as protectig the religious minorities. Moreover, in the planning of state relations certain preoccupations of a humanitarian nature manifested, however they were only targeting certain specific and determined categories, such as: diplomatic envoys (messengers) whose inviolability was known (sancti habentur legati) or non-combatant persons (women, children) which were to be spared in case of conquering cities.

From the ancient times ${ }^{6}$ certain categories of human rights were protected, in times of wars, by means of the humanitarian right ${ }^{7}$, which is sometimes presented as an integral part of the international law of human rights ${ }^{8}$.

A thorough analysis shows that between the international law and the humanitarian laws there are connections and overlappings, both aiming, with specific means, to protect the fundamental human values, firstly the right to life and other rights related to the latter.

If the humanitarian law comprises regulations by which the human rights are protected during armed conflicts; consequently, the norms which make the object of the international law of human rights embody numerous dispositions of a humanitarian nature, which target the protection of human rights and values, both in times of peace and armed conflicts.

Commencing with the 17th century, the evolution of the humanitary international law was dominated by the idea that the belligerent are not allowed to make use of forces which surpass the necessary limits to achieve the war target and that those forms of violence which are not absolutely necessary for obtaining victory are not permitted; customary norms or later named conventional norms from this domain having as subject the way to wage war ${ }^{9}$, which was considered only a relation between states, and not individuals ${ }^{10}$.

An important moment of the revolution of international humanitarian law was the adopting and signing, in the year 1864, at the international conference from Geneva, of the first humanitarian convention - "The Convention for improving the fate of wounded soldiers of the army forces in campaign" $" 11$, through which the International Committee of the Red

\footnotetext{
${ }^{5}$ Ewyzanski Ch. E., 1979, The Philosophical Background of the Doctrines of Human Rights, in Human Dignity the Internationalisation of Human Rights, coordinator A. Henkin, Aspen Institute of Humanistic Studies, p. 10.

${ }^{6}$ In the Antiquity there were rules to wage wars for every nation which sanctioned excesses committed by the invasion troops upon individuals (O’Brien,2001, International Law, Cavendish Publishing Limited, LondonSidney, p. 760); The Sumerians, Egyptians, Hittites, Persians or Jews, as well as other people in Antiquity imposed their own troops to respect humanitary rules and sanctioned their infringement (Pictet J., 1983, Développement et principes du droit internațional humanitaire, Institut Henry Dunant-Generve, Editions A. Pedone, Paris, pp. 12-19. In the Middle Ages, the Catholic Church, influenced by Thomas d'Aquino, established norms or waging war which prohibited the combating states to attach certain categories of persons, such as priest, women and children (Bădescu V.S., 2007, Umanizarea dreptului umanitar, CH Beck Publishing, Bucharest, p. 41).

${ }^{7}$ Cloşcă I. \& Suceavă I., 1992, Dreptul internațional umanitar, Şansa SRL Publishing, Bucharest, p. 35.

${ }^{8}$ Diaconu I., 1993, Drepturile omului, Romanian Institute for Human Rights, Bucharest, p. 111.

${ }^{9}$ Cloşcă I. şi Suceavă I., 1992, p. 15.

${ }^{10}$ Duculescu V., 2002, p. 47.

${ }^{11}$ Signed by Romania in the year 1874 .
} 
Cross was founded ${ }^{12}$, an organization with an extremely special role in protecting the human rights ${ }^{13}$.

The Covenant of the League of Nations ${ }^{14}$, although it did not prohibit war, it conditioned it to the preliminary accomplishment of some conciliation attempts, thus there subsequently existed certain tendencies to promote international conventions which would elaborate some humanitarian norms, in the framework of admitted rules for waging war.

The middle of the 19th century recorded a new phenomenon in the domain of human rights: the problem of their protection was debated on an international level ${ }^{15}$, however it was achieved relatively late at an international level, as an imperative of global community and only after the atrocities of the second world $\operatorname{war}^{16}$.

Thus, until the year 1945, the process of human rights international protection was described as being fragmentary, referring only to certain social categories ${ }^{17}$. These partial regulations were limited, among others, due to its intergovernmental character of the international right and, in virtue of the sovereignty right, the regime to which the state submitted its own citizens was generally considered as a issue of internal law, thus avoiding the settlement of the human rights at an international level ${ }^{18}$.

An extraordinary event in the evolution of human rights regulations at an international level was the conclusion of the Treaty of Berlin, from 1878, by which a series of states (including Romania) undertake to grant religious liberty to the persons submitted to their jurisdiction, including the national minorities. Moreover, the Convention concluded in Geneva, on the 26th of June, 1936, constitutes an important legal instrument for fighting against slavery, and the Convention in Geneva from the 30th of September 1921 and the 11th of October 1933 develops previous conventions, adopted in Paris, on the 18th of May 1904 and 1910, regarding the prohibition of trading women and children ${ }^{19}$. As well, the founders of the International Labour Organization ${ }^{20}$ decide to offer the trade unions of workers and patrons associations the right to demand the states to respect the conventions of this organization and the possibility to address the League of Nations ${ }^{21}$.

The international law of human rights, as a distinct and modern branch of public international law developed only after the second world ${ }^{22}$, the creation of the United Nations

\footnotetext{
12 The Red Cross is the successor of the „International Committee for Relief to the Wounded”, which was founded in the year 1863 (See also Pictet J., 1983, Développement et principes du droit internațional humanitaire, Henry Dunant-Generve Institute, Editions A. Pedone, Paris, p. 7).

${ }_{13}$ Geamănu G., 1983, Drept internațional public, Treaty, vol. II, Didactical and Pedagogical Publishing, Bucharest, p. 443.

${ }^{14}$ The League of Nations Covenant represents an integral part of the Peace Treaty of Versailles from the year 1919.

${ }^{15}$ Cloşcă I. \& Suceavă I., 1992, p. 31.

${ }^{16}$ Năstase A., 2004, Destinul contemporan al dreptului internațional. Reflecții dintr-o perspectivă europeană, Universitatea Publishing,,Nicolae Titulescu”, Bucharest, p. 178.

${ }^{17}$ Popescu D. \& Năstase A.,1997, Drept internațional public, Reviewed and completed edition, ,Şansa” SRL Publishing and Press, Bucharest, p. 119.

${ }^{18}$ Popescu D. \& Paşoi R., 2003, Protecția internațională a drepturilor omului, Studies of Romanian Law, new series, year 15 (48), no. 3-4, July - December 2003, Academia Română Publishing, p. 279.

${ }^{19}$ See also Geamănu G., 1977, Dreptul internațional penal şi infracțiunile internaționale, Academia Română Publishing, Bucharest, pp. 168-204.

${ }^{20}$ Founded by the Treaty of Versailles from 1919, targeting the improvement of work conditions for people and promoting liberty of association.

${ }^{21}$ Anghel I.M., 2002, Subiectele de drept internațional, 2nd Edition, Lumina Lex Publishing, Bucharest, p. 424. See also Paraschiv R.G., 2011, „Drepturi şi libertăți garantate international”, in Dinamica dreptului românesc după aderarea la Uniunea Europeană, Universul Juridic Publishing, Bucharest, p. 723-725.

${ }^{22}$ The protection of human rights took form in a series of regulations of an universal, regional of sectorial nature, as a consequence of perpetuating the practice of infringement of these rights in the states submitted to a communist regime (Năstase A., Aurescu B. \& Jura C., 2003, Drept internațional public, All Beck Publishing, Bucharest, p. 194).
} 
Organization by adopting the UN Charter ${ }^{23}$, thus permitting the redefining of preoccupations in the area of human rights.

The UN Charter only vaguely refers to the domain of human rights, the moment of reference in this sense being the Universal Declaration of Human Rights ${ }^{24}$ - the first document with universal vocation, based on the fundamental principles of human rights: liberty, equality ${ }^{25}$, universality and perpetuity.

Although not adopted through a legally binding act ${ }^{26}$, the Universal Declaration of Human Rights had and still has a great echo, becoming a veritable international instrument which stands at the basis of forming the most developed protection system of human rights known in history, the principles stipulated here being written in the constitutions of democratic states and in numerous international conventions ${ }^{27}$.

After the year 1948, over 60 conventions and declarations regarding human rights were adopted in the framework of the United Nations Organization, similarly regulating mechanism for applying them. Among the most important are: the International pact regarding the civil and political rights ${ }^{28}$, together with the optional Protocol of this $\mathrm{Pact}^{29}$, and the international Pact concerning economic, social and cultural rights ${ }^{30}$.

Also at an international level there were elaborated and adopted a series of specific juridical instruments for certain domains, such as: fighting discrimination, protecting human lives (meant to prevent and suppress genocide, war crimes and crimes against humanity) or for the protection of certain categories of people ( refugees, stateless persons, etc.).

The regional protection systems of human rights acknowledge and also protect the right of an individual (European, American and African system), however the European system established a more efficient protection system ${ }^{31}$.

In the European framework more juridical instruments were adopted by means of which fundamental human rights and liberties are being ensured, the most important of these being the European Convention of Human Rights ${ }^{32}$ which guarantees a general protection

\footnotetext{
${ }^{23}$ The UN Charter was signed on the 26th of June 1945, at the San Francisco Conference (April-June 1945) and entered into force on the 26th of October 1945. Romania became member of the United Nations Organization by means of the General Assembly Resolution of the United Nations Organization no. 995(X) from the 14th of December 1955.

${ }^{24}$ The Universal Declaration of Human Rights was adopted on the 10th of December 1948, by means of the General Assembly Resolution of the United Nations Organization no. 217A(III), with 48 votes ,for” and no vote ,against".

${ }_{25}^{25}$ In conformity with art.1 of the Declaration "all humans are born free and equal in rights".

${ }^{26}$ Concerning the different opinions regarding the role of the General Assembly Resolution of the United Nations Organization, see: Prost M. \& Kingsley Clark P., 2006, Unity, Diversity and Fragmentation of International Law: How Does the Multiplication of International Organizations Really Matter?, in the Chinese Journal of International Law, vol. 5, No. 2, pp. 354-358.

${ }^{27}$ See Gazano A., 2007, L'essentiel des Relations internationals, 4-eme edition, Gualino Publishing, Paris, p. 72.

${ }^{28}$ Adopted on the 16th of December by means of the General Assembly Resolution of the United Nations Organization 1966 no. 2100A(XX), in New York, entered into force on the 23rd of March 1976; signed by Romania on the 27th of June 1968 and approved by the Decree 212/31 October 1974 , published in the Official Gazette of S.R. of Romania no. 146/20 November 1974.

${ }^{29}$ Adopted and opened for signature by the General Assembly of the United Nations Organization by the Resolution 2200 A (XXI) from the 16th of February 1966, entered into force on the 23rd of March 1976.

${ }^{30}$ Adopted on the 16th of December 1966 by means of the General Assembly Resolution of the United Nations Organization no 2200 A (XXI), entered into force on the 19th of December 1966; signed by Romania on the 27th of June 1968 and approved by the Decree no. 212 from the 31st of October 1974, published in the Official Gazette of Romania no. 146 from the 20th of November 1974.

${ }^{31}$ Cohen-Jonathan G., 1989, La Convention Europeenne des Droits de l'homme, Economica Publishing, Paris, pp. 278 and fol.

32 Convention for the defense of human rights and fundamental liberties, adopted in Rome on the 4th of November 1950, entered in force on the 3rd of September 1953, approved by Romania on the 31st of May 1954. It is also named the European Convention of human rights.
} 
framework and the fundamental rights and liberties. The Convention was then amended by Protocols no. 3, 5, 8 and completed by Protocol no. 2 which represents an integral part of the Convention, along with its entering in force ${ }^{33}$.

As the main defense mechanism of rights in Europe we must mention the European Court of Human Rights, headquartered in Strasbourg.

The defense of human rights on the American continents has developed within the American State Organization ${ }^{34}$, commencing with the adoption of the „American Declaration of the Rights and Duties of Man”, on the $2^{\text {nd }}$ of May 1948. The interamerican system of human rights is based on the American Convention of human rights ${ }^{35}$, also known under the name of the Pact of San Jose (Costa Rica), which was subsequently completed by two additional articles: the Protocol concerning the economic, social and cultural rights, signed in 1988, and the Protocol concerning the abolition of death penalty, signed in 1990.

As control mechanisms concerning the observance of the rights stipulated in the Convention, the following were founded: the Inter-American Commission on Human Rights and the Inter-American Court of Human Rights.

The African system of human rights is based on two documents: The African Charter of human and people rights ${ }^{36}$ and the Protocol to the African Charter of human and people rights for establishing the African Court of human and people rights ${ }^{37}$, inspired from the European and American practice in the domain ${ }^{38}$.

The African Charter of human and people rights represents the first instrument of the African defense system of the human rights. This instrument creates a control mechanism of observance of the human rights, by means of the African Commission of Human and People Rights (whose competences and procedures are similar to those of the councils resembling the European and African systems), as well as by means of the African Court of Human and People Rights.

The Muslim (Islamic) law, encountered in almost 20\% of the world's population, found its source in the Koran, which, having been completed by Sunna constitutes the Islamic law named Saria (Charî'a).

On the 15th of September 1994 the Arab Charter of human Rights was adopted, which contains a generous list of rights, however in the preamble it refers to the eternal principles defined by the Muslim law and the declaration from Cairo for the human rights in Islam. Between proclaiming human rights and refusing to give priority to these norms, to the „divine", based on the fact that this may represent a form a blasphemy, there is a clear contradiction.

\footnotetext{
${ }^{33}$ Entered in force on the 21 st of September 1970.

${ }^{34}$ The constitutive Charter of the American States Organization was adopted in Bogota, on the 30th of April 1948 , in the framework of the 9th International American Conference, subsequently amended by the Protocol in Buenos Aires, from the 27th of February 1967.

${ }^{35}$ It was adopted on the 20th of November 1969 and it entered in force in the year 1978, being accepted by 26 states from the 35 members of the American States organization (it was not approved by the United States of America). This establishes a catalogue of civil and political rights, as well as a general clause concerning the promotion of economic, social and cultural rights.

36 Adopted in 1981 and it entered into force on the $21^{\text {st }}$ of November 1986. It was inspired from the corresponding treaties adopted in the framework of the United Nations Organization, as well as in the European and American systems. Unlike these afore-mentioned, the African Charter contains civil, political, economic, social and cultural rights, but also collective rights along with individual duties.

${ }^{37}$ It was adopted in the year 1988 at Ouagadougou (Burkina Faso), but it did not came into effect. These treaties were adopted under the aegis of the aegis of the Organization of African Unity, an inter-governmental organization created in 1963, headquartered in Addis-Abeba (Etiopia), which on the 9th of July 2002 was replaced with the African Unity, an organization that assembles all the states on the African continent (53) and which took over the tasks in protecting the human rights.

${ }^{38}$ To see also Mubiala M., 1999, Protocolul la Carta africană a drepturilor omului şi ale popoarelor relativ la instituirea unei Curți, Romanian Journal of Humanitarian Law, nr. 5-6 (29-30), pp. 25-28.
} 


\section{Conclusions}

The evolutions from the past decades make the Muslin law not exclusively explainable according to religious precepts, except for two countries: Afghanistan and Maldive. Nevertheless, there are still great differences between the Occidental and Arabic systems of human rights, as the Muslim religion is involved in all the aspects of the life of its adepts: a person's status, family, social and cultural life, institutions are submitted to precepts embodied in religious sources related only to the Muslim law ${ }^{39}$.

In present times, adopting a huge number of legal instruments, with the participation of the majority of the world's countries, indicates the tendency to extend international cooperation in the domain of protecting human rights by the acceptance of the sovereign states, which are more and more pronounced in the sense of protecting and observing these rights in the framework of international organizations ${ }^{40}$. Similarly, acknowledging and establishing certain rights by means of international instruments contributed to perfecting the national legislation concerning the defense of human rights.

\section{Bibliography}

Paraschiv R.G., "Drepturi şi libertăţi garantate international”, in Dinamica dreptului românesc după aderarea la Uniunea Europeană, Universul Juridic Publishing, Bucharest, 2011;

Gazano A., L'essentiel des Relations internationals, 4-eme edition, Gualino Publishing, Paris, 2007;

Bădescu V.S., Umanizarea dreptului umanitar, CH Beck Publishing, Bucharest, 2007;

Prost M. \& Kingsley Clark P., Unity, Diversity and Fragmentation of International Law: How Does the Multiplication of International Organizations Really Matter?, in the Chinese Journal of International Law, vol. 5, No. 2, 2006; 2006.

Sudre F., Drept european şi internațional al drepturilor omului, Polirom Publishing,

Năstase A., Destinul contemporan al dreptului internațional. Reflecții dintr-o perspectivă europeană, Universitatea „Nicolae Titulescu” Publishing, Bucharest, 2004;

Popescu D. \& Paşoi R., Protecția internațională a drepturilor omului, Studies of Romanian Law, new series, year 15 (48), no. 3-4, July - December 2003, "Academia Română” Publishing, 2003;

Duculescu V., Instituții de drept public şi relații internaționale în dinamică, Lumina Lex Publishing, Bucharest, 2002;

Pictet J., Développement et principes du droit internaţional humanitaire, Institut Henry Dunant-Generve, Editions A. Pedone, Paris, 1983.

\footnotetext{
39 Also see Scăunaş S., 2003, Dreptul internațional al drepturilor omului, All Beck Publishing, Bucharest, pp. 135 and fol..; Sudre F., 2006, Drept european şi internațional al drepturilor omului, Polirom Publishing, pp. 137 and fol.

${ }^{40}$ Vântu I. \& Duculescu V., 1969, Rolul reglementărilor juridice naționale şi internaționale în apărarea, garantarea şi respectarea drepturilor omului, in Juridical Studies and Research, year 14, no. 1, Bucharest, p. 52.
} 